\title{
Library Statistics of Colleges and Universities, 1961-62
}

THE LATEST statistical information concerning academic libraries is available in the Office of Education publication $\mathrm{Li}$ brary Statistics of Colleges and Universities, 1961-62, Institutional Data (OE15023-62). All institutions of higher education in the United States and its possessions should have received a copy during March.

For the second consecutive year there was a marked increase in the number of institutions returning completed questionnaires (See Table A).

Coverage was even more complete when measured against enrollment. The reported 1,862 institutions enrolled 3,821,000 or 98.2 per cent of $3,891,000$ degree-credit students announced by the Office of Education in the fall of 1961. Last year, the figures were $3,430,000$ students or 95 per cent.

Table 1 of the survey contains eighteen items of management information for each institution as of June 30, 1962. Included for the first time are data indicating the control (public or private) and type of each institution. The seven types of institutions are universities, liberal arts colleges, teachers colleges, technological schools, theological schools, junior colleges, and other professional schools.

These two specifications should enable the librarian to compare more easily the operation of his library, as well as the size of his staff and its financial resources with those of similar libraries. In addition, a more meaningful comparison can be made with ALA-recommended quantitative standards for college and junior college libraries.

The salary data in Table 2 of the survey relate only to full-time staff members as of September 1, 1962. The table does not include salaries of personnel who are employed for less than the full academic year (9-10 months). The number of personnel is reported for each category (associate or assistant librarian, department or division heads, etc.) as well as the highest and lowest annual salary actually received. When a category has only one salary, it is entered in the column headed "highest salary."

As in previous years, a substantial number of institutions reported some full-time staff members with 9-10 months of service and some full-time staff members with 11-12 months of service. In the two prior surveys these institutions were

TABLE A

Number and Per Cent of Respondents to Library Statistics Survey, 1959-62

\begin{tabular}{l|r|r|r}
\hline \hline & $1959-60$ & $1960-61$ & $1961-62$ \\
\cline { 2 - 4 } Total number of institutions* & 1,952 & $\dagger 1,991$ & 1,985 \\
Number of respondents & 1,393 & 1,666 & $\ddagger 1,862$ \\
Response rate (per cent) & 71 & 84 & 94 \\
\hline
\end{tabular}

* Institutions with students taking courses creditable toward bachelor's or higher degrees, as listed in the annual publication, Opening (Fall) Enrollment in Higher Education, Institutional Data.

$\dagger$ In this survey, major branch libraries of complex institutions were counted separately. The institutional total was 1,975

$¥$ Includes $1960-61$ data for 91 institutions. 
assigned to either category according to the number of months the majority of the staff was employed. For example, when over half of the staff of a library worked 9-10 months during the year rather than 11-12 months, the entire staff of the library was listed in the 9-10 month category. However, this year's table allows scope for designating those institutions which employ full-time staff members on either a 9-10 or a 11-12 months basis, or both.

Agreement was reached concerning the treatment of "contributed services" 1 by

${ }^{1}$ Contributed services (C.S.). This term is defined as the estimated monetary value of work performed by members of religious orders, such as clerics, nuns, and priests. It should be emphasized that all indications of contributed services are based on 11.12 months of employment. the inclusion of a separate salary schedule for such services in the questionnaire. As a result, Table 2 of the survey designates clearly which salaries are computed on a contributed service basis.

Table B offers a comparison of the totals of various management data for the years 1959-62. The table includes data on annual per cent changes. While total library collections, personnel, etc. increased appreciably, so did total enrollments in academic institutions as shown in Table C.

Table $\mathrm{D}$ denotes the twenty-five largest college and university libraries in the United States as of July 30, 1962. They are listed in order of the size of the volume collection: the numbers in pa-

TABLE B

Total Library Resources of INSTITUTIONS OF Higher EDUCATION IN THE United States ANd its Possessions 1960-62*

\begin{tabular}{|c|c|c|c|c|c|c|c|c|}
\hline & & & & $1959-60$ & $1960-61$ & $\begin{array}{l}\text { Per cent } \\
\text { of Change }\end{array}$ & $1961-62$ & $\begin{array}{l}\text { Per cent } \\
\text { of Change }\end{array}$ \\
\hline $\begin{array}{l}\text { Number of institutions } \\
\text { (fall enrollment) } \\
\text { Library Collection }\end{array}$ & s & . & . & 1,952 & 1,975 & & 1,985 & \\
\hline Volumes & . & . & . & $176,721,000$ & $189,100,000$ & 7.0 & $201,914,000$ & 6.8 \\
\hline Volumes added & . & . & . & $8,415,000$ & $9,396,000$ & 11.7 & $10,949,000$ & 16.5 \\
\hline $\begin{array}{l}\text { Periodicals received } \\
\text { Personnel (FTE) }\end{array}$ & . & . & . & $1,271,000$ & $1,399,000$ & 10.1 & $1,487,000$ & 6.3 \\
\hline Professional & . & . & . & 9,254 & 9,674 & 4.5 & 10,376 & 7.3 \\
\hline $\begin{array}{l}\text { Nonprofessional } \\
\text { Expenditures }\end{array}$ & . & . & . & 8,860 & 9,759 & 10.1 & 10,807 & 10.7 \\
\hline Total & . & . & . & $137,245,000$ & $158,904,000$ & 15.8 & $184,017,000$ & 15.8 \\
\hline $\begin{array}{l}\text { Salaries \& wages } \\
\text { Books \& other }\end{array}$ & . & . & . & $84,175,000$ & $97,671,000$ & 16.0 & $111,891,000$ & 14.6 \\
\hline library materials & & . & . & $40,760,000$ & $47,695,000$ & 17.0 & $56,377,000$ & 18.2 \\
\hline $\begin{array}{l}\text { Binding } \\
\text { Other operating }\end{array}$ & . & . & . & $4,852,000$ & $5,606,000$ & 15.5 & $6,234,000$ & 11.2 \\
\hline expenditures & . & . & . & $7,458,000$ & $7,932,000$ & 6.4 & $9,515,000$ & 20.0 \\
\hline
\end{tabular}

* These preliminary figures will be adjusted when valid estimates have been made of nonrespondent institu tions.

TABLE C

Opening Fall Degree-Credit Enrollment; Aggregate United States 1959-61

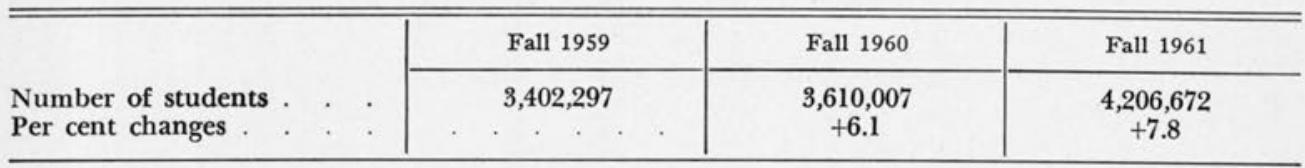


TABLE D

COLlege ANd UnIVERSITY LibraRy Statistics-1961-62

(The 25 largest in the United States)

\begin{tabular}{|c|c|c|c|c|c|c|c|c|}
\hline Rank & Institution & Total volumes & Volumes added & $\begin{array}{l}\text { Library materials } \\
\text { and binding }\end{array}$ & $\begin{array}{l}\text { Total } \\
\text { staff }\end{array}$ & $\begin{array}{l}\text { Total operating } \\
\text { expenditures }\end{array}$ & $\begin{array}{l}\text { Exp. per } \\
\text { student } \\
\text { (in dollars) }\end{array}$ & $\begin{array}{c}\text { Exp. } \\
\text { percentage }\end{array}$ \\
\hline 1 & Harvard University & $6,931,293$ & $201,655(1)$ & $1,023,889(4)$ & $432(1)$ & $4,284,586(1)$ & $367(1)$ & $6.2(2)$ \\
\hline 2 & Yale University & $4,572,893$ & $90,015(7)$ & $781,765(6)$ & $311(3)$ & $2,004,285(8)$ & 242 ( 3) & $4.5(5)$ \\
\hline 3 & Univ. of Illinois & $3,525,820$ & $142,436(3)$ & $810,445(5)$ & $266(6)$ & $2,592,276(4)$ & $81(16)$ & $2.7(12)$ \\
\hline 4 & Univ. of Michigan & $3,049,715$ & $119,976(5)$ & $627,514(8)$ & $261(7)$ & $2,471,292(5)$ & 88 (13) & 2.9 (11) \\
\hline 5 & Columbia University & $3,026,464$ & $86,240(8)$ & $558,846(11)$ & $298(4)$ & $2,153,156(7)$ & $129(11)$ & $2.9(10)$ \\
\hline 6 & Univ. of Cal_-Berkeley & $2,701,186$ & $106,710(6)$ & $1,097,598$ ( 2$)$ & $369(2)$ & $3,812,997$ ( 2$)$ & $161(10)$ & \\
\hline 7 & Stanford University & $2,287,332$ & $71,323(17)$ & $437,628(16)$ & $193(11)$ & $1,605,939(12)$ & $169(7)$ & $3.3(9)$ \\
\hline 8 & Cornell University & $2,278,046$ & $135,260(4)$ & $684,283(7)$ & $280(5)$ & $2,252,913(6)$ & $189(4)$ & $3.7(7)$ \\
\hline 9 & University of Chicago & $2,210,062$ & $82,284(12)$ & $457,213(15)$ & $160(15)$ & $1,531,950(15)$ & $168(8)$ & \\
\hline 10 & Univ. of Minnesota & $2,072,285$ & $61,423(20)$ & $603,345(9)$ & $160(16)$ & $1,720,109(10)$ & $41(24)$ & $2.3(16)$ \\
\hline 11 & Indiana University & $1,828,992$ & $82,778(11)$ & $571,812(10)$ & $162(14)$ & $1,379,722(16)$ & $48(22)$ & \\
\hline 12 & Princeton University & $1,754,580$ & $67,294(19)$ & $347,343(21)$ & $168(13)$ & $1,099,322(20)$ & $277(2)$ & \\
\hline 13 & Univ. of Pennsylvania & $1,744,680$ & $60,750(21)$ & $493,247(13)$ & $193(10)$ & $1,374,711(17)$ & $76(17)$ & $2.4(14)$ \\
\hline 14 & Univ. Cal__Los Angeles & $1,719,359$ & $154,801$ ( 2$)$ & $1,085,073$ ( 3$)$ & $257(8)$ & $3,083,285$ ( 3$)$ & $163(9)$ & \\
\hline 15 & Northwestern University & $1,666,200$ & $73,681(16)$ & $361,714(20)$ & $128(20)$ & $1,111,310(18)$ & $70(19)$ & $3.6(8)$ \\
\hline 16 & Duke University & $1,540,063$ & $47,041(24)$ & $480,416(14)$ & $116(21)$ & $1,106,809(19)$ & $181(5)$ & $5.3(3)$ \\
\hline 17 & Univ. of Wisconsin & $1,527,432$ & $78,664(15)$ & $544,918(12)$ & $155(17)$ & $1,551,552(14)$ & $47(23)$ & $2.4(15)$ \\
\hline 18 & Ohio State & $1,520,597$ & $79,953(13)$ & $422,879(19)$ & $190(12)$ & $1,556,153(13)$ & $57(21)$ & $2.4(13)$ \\
\hline 19 & Univ. of Texas & $1,508,262$ & $86,203$ ( 9$)$ & $1,242,171(1)$ & $137(18)$ & $1,978,153$ ( 9$)$ & 85 (14) & \\
\hline 20 & Univ. of North Carolina & $1,283,109$ & $69,284(18)$ & $425,589(18)$ & $108(22)$ & $1,051,696(21)$ & $105(12)$ & $4.0(6)$ \\
\hline 21 & Johns Hopkins University & $1,207,246$ & $83,080(10)$ & $198,785(24)$ & $83(24)$ & $637,012(25)$ & $83(15)$ & $2.2(17)$ \\
\hline 22 & Univ. of Washington & $1,173,496$ & $79,431(14)$ & $437,125(17)$ & $226(9)$ & $1,691,865(11)$ & 73 (18) & \\
\hline 23 & Brown University & $1,170,755$ & $47,410(23)$ & $214,619(22)$ & $95(23)$ & $707,155(23)$ & $171(6)$ & $6.3(1)$ \\
\hline 24 & University of Virginia & $1,155,488$ & $50,878(22)$ & $193,872(25)$ & $82(25)$ & $642,363(24)$ & $65(20)$ & $4.8(4)$ \\
\hline 25 & New York University & $1,148,119$ & $30,794(25)$ & $214,446(23)$ & $134(19)$ & $1,007,310(22)$ & $31(25)$ & \\
\hline
\end{tabular}


rentheses after each entry in the remaining columns indicates the rank of that library for that particular column. For example, Harvard ranks first in volume collection, but Brown University ranks first in expenditure percentage.
A complete analysis of all the data contained in the survey will be available early next year.-Theodore Samore, $\mathrm{Li}$ brary Services Branch, $U$. S. Office of Education.

\section{Current Selection Service}

Richard K. Gardner, librarian of Marietta (Ohio) College since 1959 has been named editor of a new publication, as yet unnamed, to assist college and university libraries in book selection activities. The publication is to be directed primarily to undergraduate college libraries with book funds of $\$ 30,000$ or less; it is hoped, however, that it may also be useful in book selection activities of other libraries.

The new service will be issued under the direction of ACRL. Though supported initially by a grant of $\$ 150,000$ from the Council on Library Resources, the publication is expected to become self-supporting.

Need for a current book selection service for college and other libraries having similar problems has been apparent for some time, and ALA has undertaken a study to determine a rapid and efficient method of disseminating information while it is still current. The process to be used for printing the new periodical should provide such a method. The publication will be produced from typed cards, using a sequential camera for composing pages. This method also should make possible cumulations and subject lists, using the same cards.

The periodicals staff will consist of the editor, two assistant editors and two clerk typists. Books will be reviewed by subject experts working in undergraduate college instruction. An estimated ten thousand to fifteen thousand titles will be considered annually, and from two to three thousand titles will be reported. The service is expected to review books simultaneous with publication or soon thereafter. Coverage will include, initially, publications in English wherever published. Representative publications will be included, in addition to "best" publications. Coverage of titles in other languages will be considered later.

Mr. Gardner's appointment is effective July 1. Appointed to serve on the editorial board of the publication are Leo M. Weins, H. W. Wilson Co.; Ellsworth Goodwin Mason, head librarian, Coburn Library, Colorado College; James H. Richards, Jr., head librarian, Carleton College, Northfield, Minn.; Robert H. Muller, associate director, University of Michigan Library; Wyman Parker, librarian, Wesleyan University, Middletown, Conn.; Eileen Thornton, librarian, Oberlin College, and Joseph Reason (now on leave of absence), director of libraries, Howard University. The president of ACRL will serve as chairman of the editorial board, and the ACRL executive secretary will act as liaison with ALA headquarters.

Suggestions for a name for the new periodical service are solicited by ACRL and ALA. Such suggestions should be sent to ALA headquarters, 50 E. Huron St., Chicago 11. A one-year subscription will be awarded to the person suggesting the name selected for the publication. 